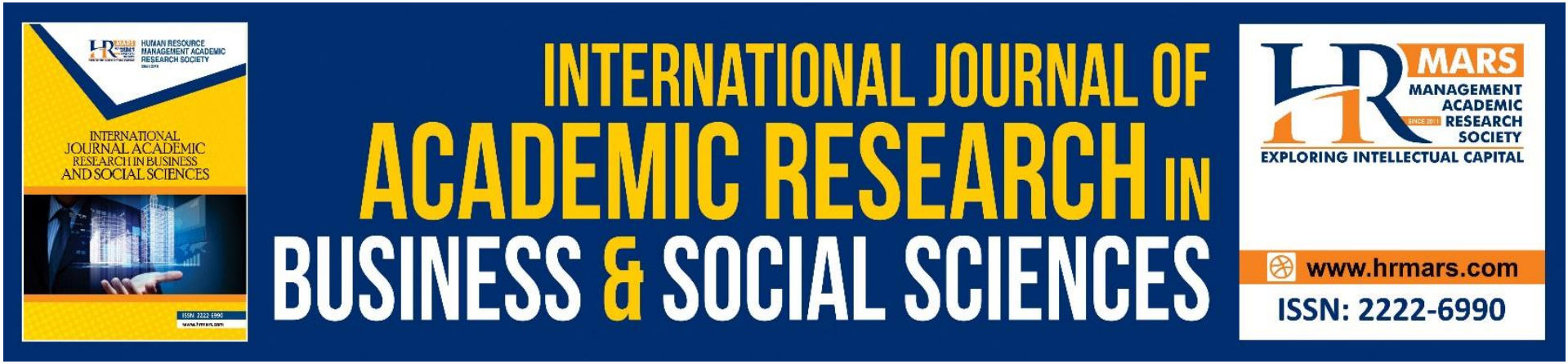

\title{
A Review on Empowering Farmers through Technology Adoption towards Poverty Alleviation in Developing Countries
}

Muthubandage Mahinda Herath, Nobaya Ahmad, Mohammad Mujaheed Hassan \& Wan Munira Wan Jaafar

To Link this Article: http://dx.doi.org/10.6007/IJARBSS/v11-i11/11661

DOI:10.6007/IJARBSS/v11-i11/11661

Received: 07 September 2021, Revised: 10 October 2021, Accepted: 30 October 2021

Published Online: 09 November 2021

In-Text Citation: (Herath et al., 2021)

To Cite this Article: Herath, M. M., Ahmad, N., Hassan, M. M., \& Jaafar, W. M. W. (2021). A Review on Empowering Farmers through Technology Adoption towards Poverty Alleviation in Developing Countries. International Journal of Academic Research in Business and Social Sciences, 11(11), 1785-1805.

Copyright: (c) 2021 The Author(s)

Published by Human Resource Management Academic Research Society (www.hrmars.com) This article is published under the Creative Commons Attribution (CC BY 4.0) license. Anyone may reproduce, distribute, translate and create derivative works of this article (for both commercial and non0-commercial purposes), subject to full attribution to the original publication and authors. The full terms of this license may be seen at: http://creativecommons.org/licences/by/4.0/legalcode

Vol. 11, No. 11, 2021, Pg. 1785 - 1805

http://hrmars.com/index.php/pages/detail/IJARBSS

JOURNAL HOMEPAGE

Full Terms \& Conditions of access and use can be found at http://hrmars.com/index.php/pages/detail/publication-ethics 


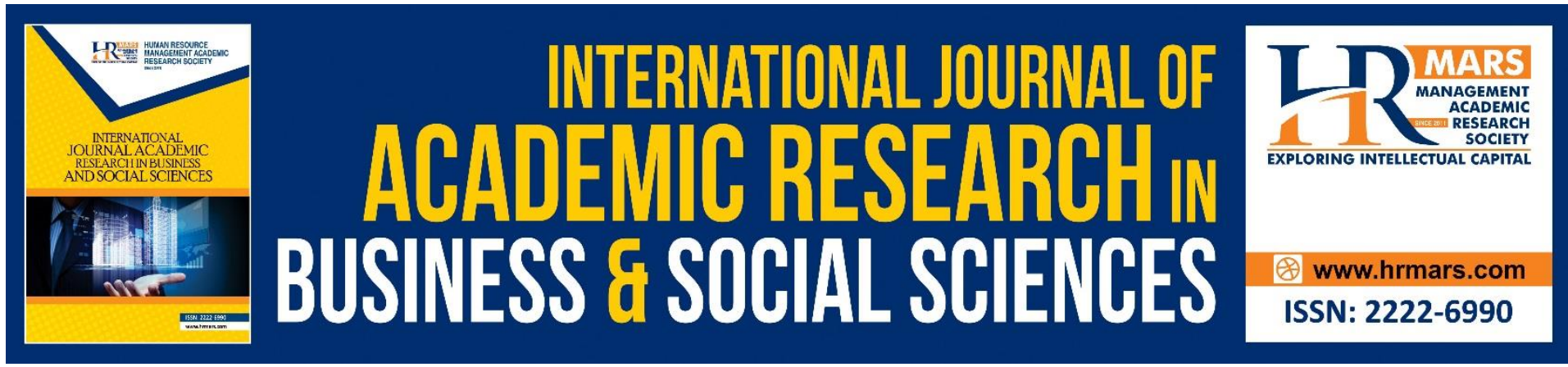

\title{
A Review on Empowering Farmers through Technology Adoption towards Poverty Alleviation in Developing Countries
}

\section{Muthubandage Mahinda Herath ${ }^{1}$, Nobaya Ahmad², Mohammad Mujaheed Hassan ${ }^{3}$ \& Wan Munira Wan Jaafar ${ }^{4}$ \\ Department of Social and Development Sciences, Faculty of Human Ecology, Universiti Putra Malaysia}

Email: ${ }^{1}$ mahindaniphm@gmail.com, ${ }^{2}$ nobaya@upm.edu.my, ${ }^{3}$ mujaheed@upm.edu.my,

${ }^{4}$ wanmunira@upm.edu.my

\begin{abstract}
Poverty alleviation is critical to improving the living standards of communities that earn less than \$1 per day; the majority of them work in agriculture in developing countries. Lack of technological adoption is a significant factor influencing agricultural performance and minimizes the income of the poor rural community in many developing countries. The primary goal of this paper is to empirically validate the link between empowerment and technology adoption in the context of poverty alleviation. The current study conducted a review study to assess the influence of empowerment and technology adoption on poverty alleviation within the agricultural community in developing nations from 2010 to 2020, identified 11 studies that fulfilled our inclusion criteria. Technology adoption can empower individuals and alleviate poverty in many ways. The cumulative impact of technology interventions on empowerment is determined by how these factors interact independently and cohesively. Improved technology adoption is essential, but it is not enough to prevent poverty at the domestic level. Agriculture science and technology, community development approaches, policies, and systematic structure need to address poverty alleviation. The empowerment approach provides a holistic vision of sustainable community development. Finally, empowerment is essential for poverty alleviation through technology adoption in developing countries.
\end{abstract}

Keywords: Empowerment, Technology Adoption, Poverty Alleviation, Income Generation, Farmers

\section{Introduction}

One of the most distressing and well-known human problems is poverty. According to scientific reports, poverty directly affects $10 \%$ of the community in the World, with 630 million people were suffering in poverty in 2018 (Rita \& Laosebikan, 2021). These people currently live in extreme poverty by defined as having an income of less than USD 1.90 per day for an individual (Halkos \& Gkampoura, 2021; Sutter et al., 2019). Furthermore, Halkos \& Gkampoura (2021) discuss on level of poverty based on their income per day as; "ultra- 
poverty" (< USD 0.54/ day); "medial poverty" (USD 0.54- USD 0.81/ day); "subjacent poverty" (USD 0.81- USD 1.08/ day). Food insecurity is another indicator of poverty among the community; in 2019, nearly 750 million people, or nearly one in every ten people worldwide, faced extreme food shortages (FAO, 2020). Uziak \& Lorencowicz (2017) argue that global food demand is expected to double over the coming next 50 years, due to the global population, especially in developing countries. Thus, poverty is the most significant barrier and challenge to sustainable empowerment globally, especially in developing countries (Hussain et al., 2014; Rita Ifeoma et al., 2018). The researchers argued that all nations have the right to alleviate poverty in their communities and provide sustainable community development for their communities.

In comparison to other countries, a developing countries have a less developed industrial base and a low Human Development Index (HDI), with a less sophisticated and matures economy (Jeníček, 2011). Based on Gross National Income per capita, the World Bank defines the world's economies into four categories: high, upper-middle, lower-middle, and low income countries (Talero \& Gaudette, 1996). Economic development occupies a unique place in the context of the developing countries, and its relevance in the global economy continues to expand. There are numerous reasons to monitor the progress of developing countries in the context of the global economy. It has one of the world's largest economies. Due to economic change with the related economic crisis, transition economies are integrated into the developing countries, even if their social development levels are higher than in most traditional developing countries. In transition economies, poverty, unemployment and corruption provide a complicated array of issues (Jeníček, 2011).

Poverty is described as a lack of knowledge, attitude, culture, or life force (Hussain et al., 2014), a scarcity of resources, and providing those resources would enable entrepreneurship to succeed (Sutter et al., 2019), someone whose income is insufficient to meet basic needs such as housing, food, clothes, and other necessities (Rita \& Laosebikan, 2021), a serious socio-economic phenomenon characterized by a person's inability to obtain the essential necessities of life (Ozoh et al., 2020). It is described as a lack of access to basic requirements (needs and wants), a lack of access to productive sources, inefficient utilization of public resources, and exclusion structures (Rita Ifeoma et al., 2018). Poverty usually measures from a financial perspective, but it has multidimensional in practice. As a result, poverty will include a wide range of issues beyond economic hardship, such as lack of capability, low self-esteem, marginalization, prejudice, social exclusion, and poor health (Ajani et al., 2015). According to the above scientific data, poverty alleviation is more critical. Poverty alleviation means longterm development in a community to enhance sustainable living conditions (Halkos \& Gkampoura, 2021). They argue that poverty alleviation is inextricably linked to development; the goal of any development project in reducing poverty is to make long-term improvements in people's quality of life, not just short-term gains that go away at the end of a project period. In this sense, technology adoption is a critical element in successfully using capital to achieving socio-economic empowerment among the agricultural communities in developing countries (Ozoh et al., 2020). Rodriguez-Pose \& Hardy (2015) discuss that rural community development approaches must include provisions for the poor to guarantee that rural development programs should focus the poverty alleviation. 
According to the above facts, poverty is a major issue in developing countries. Poverty is caused by a scarcity of resources, and providing those resources would enable entrepreneurship to succeed (Sutter et al., 2019). As a result, poverty will include a wide range of issues beyond economic hardship in developing countries, such as lack of capability, low self-esteem, marginalization, prejudice, social exclusion, and poor health (Ajani et al., 2015). Meanwhile, poverty, inequality, and food security are global concerns that must be "won or lost in rural areas of developing countries" (Rodriguez-Pose \& Hardy, 2015). Thus, a clear understanding of poverty in developing countries is required in this context in order to alleviate poverty. Therefore, the core purpose of this study is to investigate the relationship between empowerment and technology adoption in the context of poverty alleviation among the agricultural community in developing countries.

Community development can be used to help people get out of poverty. It is a process of bringing people together to find a solution to common issues in a person, group, organization, or community by empowering them through collaborative action (Ahmad et al., 2013; Bishop \& Phillips, 2012; Brennan, 2007). Purcell (2012) argues that the "community development" field considers community changes, community justice, inspiring oppression and disparities, handles community segregation, and develops community cohesion. Ahmad et al (2013) elaborate more, focusing on economic empowerment through capacity development. Community empowerment is critical for the socio-economic development of the nations in the World. It is a necessary prerequisite for empowering the community to the optimal level in order to enhance the socio-economic conditions of the individuals of every country (Sarania, 2015). Therefore, empowerment is the most critical approach in community development, especially among the agricultural community in developing countries.

Empowerment can be accomplished by community education and participation. It means that people who are powerless, poor, low incomes, and marginalized, who are impoverished, suffer from poverty can be empowered by exposure to livelihood skills development activities (Latopa, 2015). Indeed, technology adoption directly contributes to the improvement of agricultural livelihood activities in developing countries. Mujtaba et al (2016) argue on the various ways of empowerment in community development: "empowerment is a process through which build their capacities and competencies, to gain or achieve results for themselves." Meantime, Gergis (1999) discuss that the center of developing thinking positively towards economic development as a response to the economic crises. Tanga \& Mundau (2014) discuss the impact of empowerment in the donor-funded project; the most significant stakeholder in this situation is the affected community in developing countries, which must be empowered to achieve long-term economic, social, and cultural development. In this scenario, the most marginalized group in the agricultural sector in developing countries, the most impoverished community, requires outside assistance to rehabilitate their lives by developing sufficient knowledge and other related support. These issues related to poverty can be addressed by encouraging the community through agricultural development programs that allow them to practice technology adoption for empowerment in the agricultural sector (Ajani et al., 2015). Indeed, technology adoption helps them by introducing a viable development strategy with the cooperation of farming communities in developing countries.

Increased production and productivity have resulted from the increasing adoption rate of technological development across numerous disciplines, especially in the agricultural sector. 
Technology plays a critical role in several fields as a vehicle for socio-economic development (Ugochukwu \& Phillips, 2018). Berihun et al (2014) argues that many scholars have conducted comprehensive research on the role of agricultural technology adoption in alleviating poverty and food insecurity, if agricultural technology adoption rates are lacking in developing countries, improving the livelihoods and empowerment of rural farm households by agricultural productivity would remain a ridiculous concept. Therefore, productive agricultural technologies need to be adopted to increase productivity and efficiency and thus improve the well-being of the rural poor. The agricultural community can be empowered by increasing agricultural production on the farm by practicing technology adoption using agricultural inputs to produce more per unit of land, produce value-added products, increase product quality, minimize the cost of production, or expand the cultivation land (Kassie et al., 2020).

According to the World Bank (2008), the adoption of technologies that increase productivity in developing countries has contributed to the empowerment of communities known as the Green Revolution (Hailu et al., 2014). It is widely accepted that sustainable empowerment is impossible without social and human development and that such development is based entirely on many variables such as equal access to resources, opportunities to gain knowledge on technology, and so on (Cremin \& Nakabugo, 2012). In this context, technology adoption is highly significant for being an empowered farming community. Therefore, social scientists are interested in studying how social and economic empowerment can achieve through technology adoptions. None has yet thoroughly focused on the relationship between empowerment and technology adoption towards poverty alleviation in the agricultural sector in developing countries.

\section{Methodology of the Study}

This study mainly focuses on the farming community in developing countries as a focal group in this study. This is a systematic review study to examine the effect of empowerment and technology adoption towards poverty alleviation among the farming community in developing countries. Researchers used Google Scholars, Science Direct, and Scopus to discover the most relevant academic papers. The researchers primarily concentrate on the aforementioned online search engine, the limited accessibility to other databases available and the study being an exploratory study; hence the use of the databases specified is deemed sufficient.

As a result of this search, various journal articles, conference papers, and other types of study were discovered, and materials were critically read to decide which articles could be used in the systematic review article. The systematic research article search is carried out using keywords and principles from various disciplines of academia that deal with the relationship between technology adoption and empowerment towards addressing the rural development issues, especially poverty alleviation. The following keywords were considered to cover the empowerment, technology adoption, and poverty alleviation aspects of our research issue; "empowerment", "technology adoption", "poverty alleviation", "income generation", "farmers". Following the extensive reading, the most important papers were gathered that were considered the best contest within the frameworks of the current issues concerning empowerment and technology adoption towards poverty alleviation. The study reviewed all collected scientific research articles based on their background, objectives, types of 
participants, concept, methodology, findings, discussion, conclusion, and implementation of policies (Peters et al., 2015; Ramdhani et al., 2014). A systematic search of research articles was conducted for the period 2010 to 2020. Articles that were not written in English published before 2010, and book reviews were rejected. The 156 potential research papers were identified using keywords in a search dealing with developing countries, written in English, peer-reviewed, and non-peer-reviewed articles (Figure 1). The eleven articles were chosen for this study. Six of the eleven articles were found on Google Scholar, four on Science Direct, and one on Scopus.

\section{Selection Procedure}

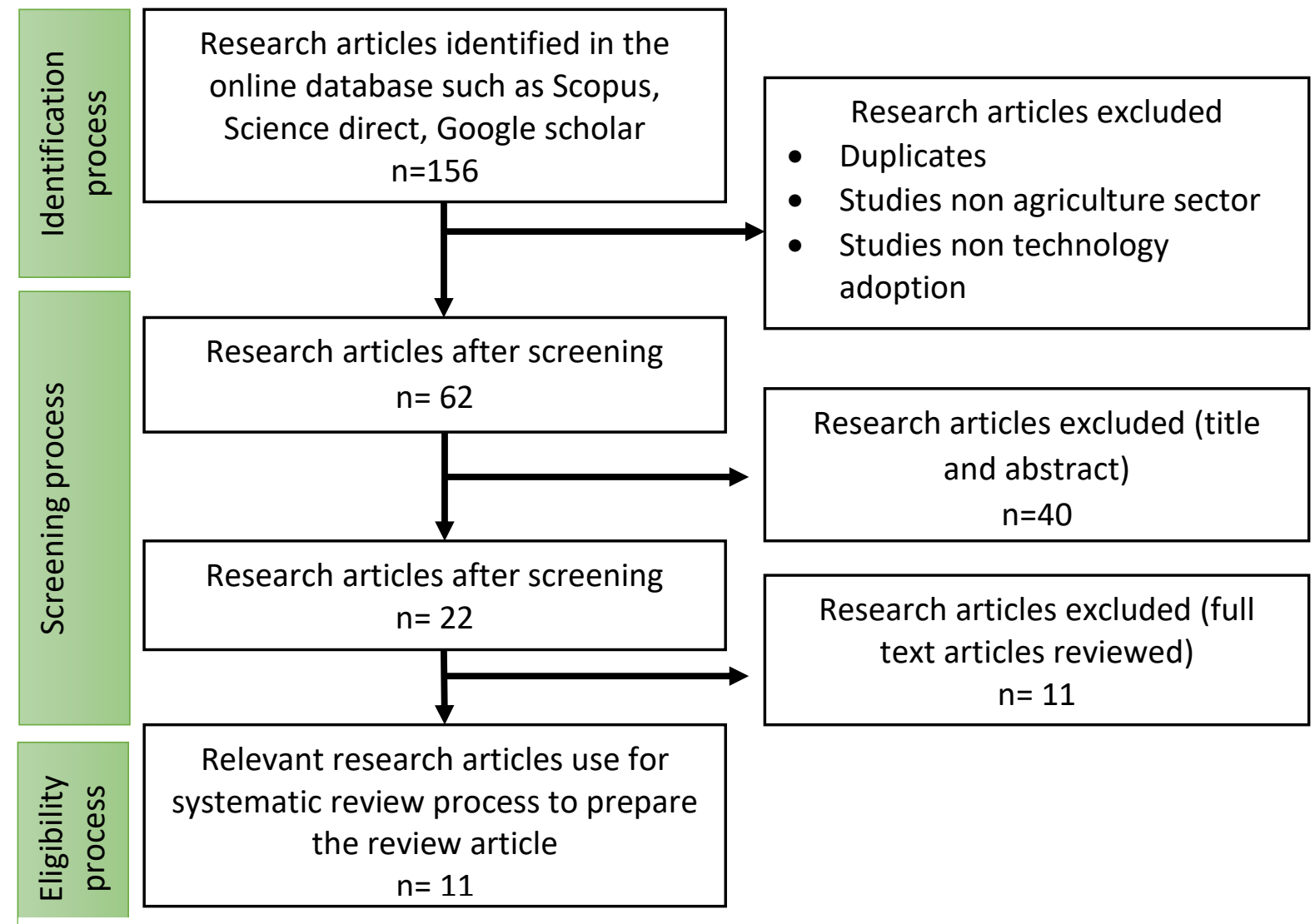

Figure 1: Flow diagram for the scoping analysis method using Preferred Reporting Items for Systematic Reviews

Source: Peters et al (2015) 
The Exclusion and Inclusion Procedure

Table 1: Selection criteria based on exclusion and inclusion

Type

Exclusion

\section{Criteria}

- The title of the article makes no mention of "empowerment, technology adoption, and poverty alleviation."

- The abstract does not mention the central theme, the concept of empowerment, or technology adoption.

- The article does not mention or focused on developing countries.

Inclusion - The research articles mention the concept of empowerment, poverty alleviation, and technology adoption or related terms.

- The research articles mentioned or focusing on developing countries.

- The relevant research articles have published from 2010 to 2020.

Empirical review of community empowerment in the agriculture sector and how to practice technology adoption towards poverty alleviation

In this Systematic Literature Review (SLR) study, researchers always make an effort to analyze research articles to deliver a high-quality end product critically. This systematic literature review study is conducted based on a wide range of research questions, such as; (1) How do agricultural development projects use technology to empower farmers in the agriculture sector? (2) What types of technologies are used by the farmers in the agriculture sector? (3) What the norms and attitudes of farmers are in obtain novel technology? (4) What are the recommendations of applying technology adoption in the agriculture sector in developing countries?

\section{Result}

Figure 2 and 3 illustrates the research locations in different parts of the World that were evaluated for investigation as part of this SLR study.

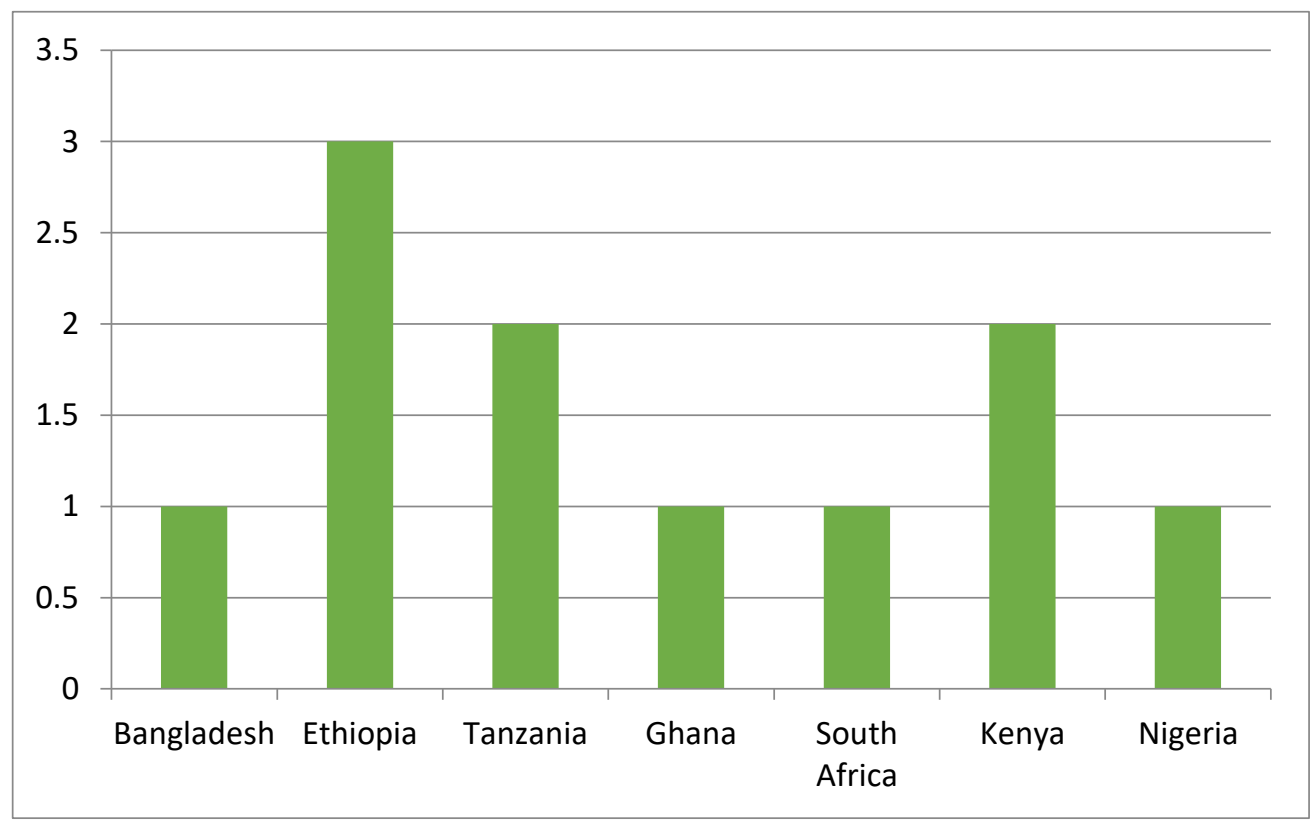

Figure 2: Number of research conducted in different continents in the world 


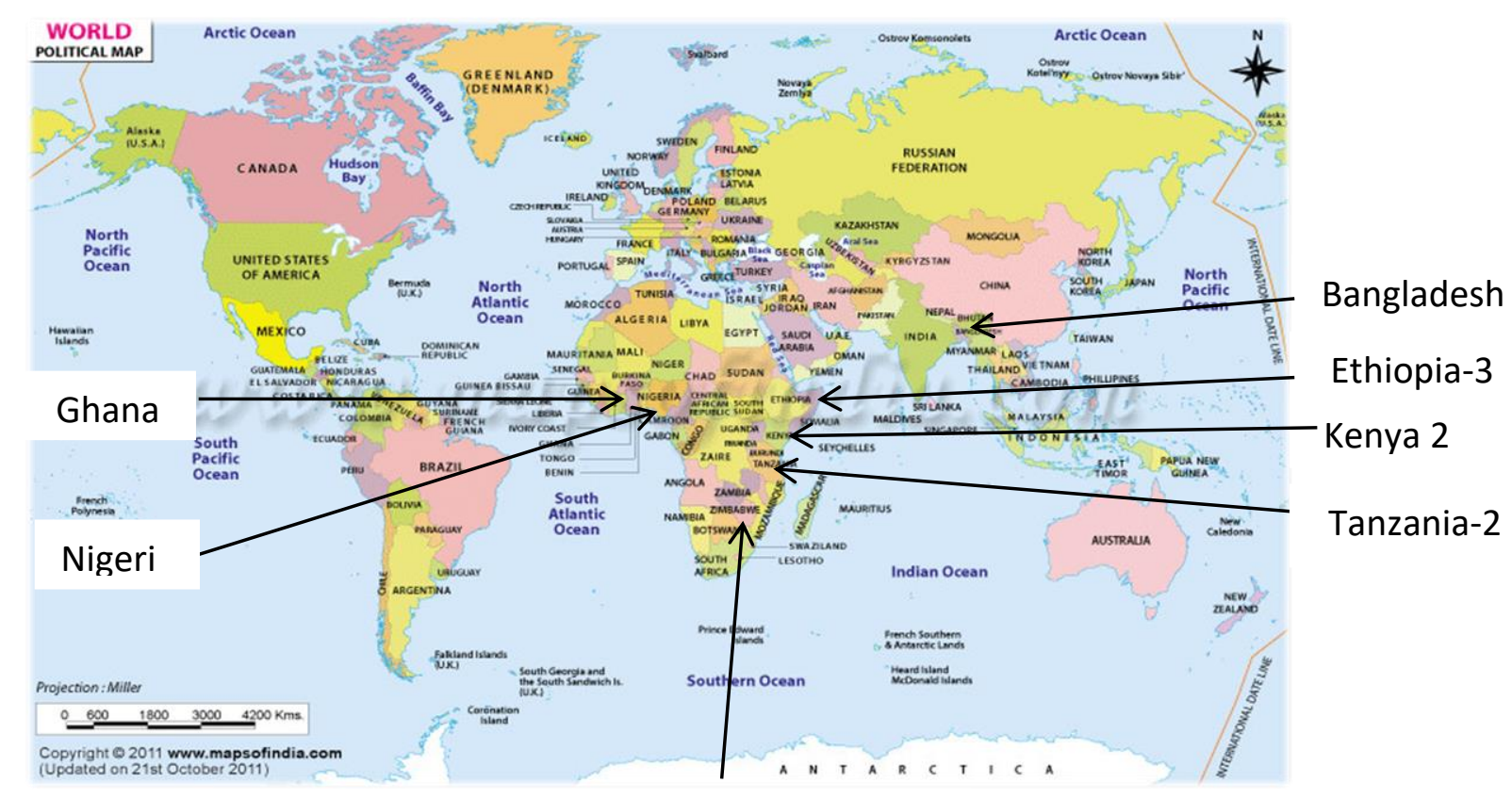

Chinyanja Triangle, Southern

Figure 3: The research distributing among the world

Source: Based on the current literature review (2021)

\section{Technology Adoption as a tool for the Empowerment of Farmers in the Agriculture Sector}

In the agricultural sector, technology adoption has focused on critical responsibilities at various phases of crop production, from land preparation to marketing, including pre-harvest; seeding, irrigation, fertigation, pest and disease control, weeding, and post-harvest activities; harvesting, packaging, transporting, pack- house operation, value-added production, and marketing (Kassie et al., 2020). The administrative bodies must be set up correctly to adopt technology effectively among the community. e.g., self-help groups, agriculture producer organizations, farmers-based cooperatives, and so on. That can be used to disseminate knowledge by collaborating various agricultural development programs at the village, province or national level to empowerment the community. These organizations assist in coordinating developmental programs with different stakeholders, either governmental or non-governmental (Muzari et al., 2012; Theis et al., 2018).

The primary goal of implementing technology in the agricultural sector is to increase productivity to access adequate facilities such as food, nutrients, shelter, and wealth. Therefore, these factors both directly and indirectly lead to their empowerment. According to those who suggest using technology to improve the economy, food and other essential services can directly contribute to community empowerment (Table 2). 
Table 2: Summary of the technology adoption in the agriculture sector towards development

\begin{tabular}{|c|c|c|}
\hline Author & Assumption of study & Technology adoption effect for empowerment \\
\hline (Lwoga et & Evaluate rural & Farmers' knowledge and information needs, as well as their \\
\hline al., 2011) & $\begin{array}{l}\text { Tanzanians' access to } \\
\text { and use of agricultural } \\
\text { knowledge and } \\
\text { information. }\end{array}$ & $\begin{array}{l}\text { information-seeking practices, were location-specific. } \\
\text { Farmers' primary sources of information were primarily } \\
\text { local (neighbors, friends, and family), with public extension } \\
\text { agencies coming in second. Aside from radio and cell } \\
\text { phones, new technology (such as the internet and E-mail) } \\
\text { and printed materials were used seldom, despite their } \\
\text { widespread availability in the communities. }\end{array}$ \\
\hline
\end{tabular}

(Hailu et Focused

al., 2014) determining

on

factors that influence

agricultural

technology adoption

and assessing the impact of adoption on farm income.

(Mango et The goal is to al., 2018) determine elements the that influence smallholder farmers' decisions to adopt small-scale irrigation and to estimate the impact of adoption on household earnings.

(Odini, The purpose of the 2014) study was to figure out farming practices of small-scale women farmers and their information needs and information-seeking habits to improve food security and identify obstacles they confront.

(Ozoh et To determine al., 2020) women microbusiness access to have
According to the regression results, the introduction of agricultural technology has a positive and significant impact on farm revenue with adopters outperforming nonadopters. Irrigation use, land ownership right security, credit availability, distance to the nearest market, plot distance from the homestead, off-farm participation, and tropical livestock unit were found to influence farm households' agricultural technology adoption decisions.

Examines the elements that influence small-scale irrigated farming's adoption as a climate-smart agriculture practice and its impact on smallholder farmers' income and examine how it affects people's livelihoods. In order to effectively adapt to climate unpredictability and change in the region, policy strategies for targeting out and up scaling small-scale irrigation adoption are recommended.

Women farmers in Kenya's Vihiga County are looking for knowledge to help them achieve food security. The research discusses that existing information services, systems, and communication channels be improved based on the findings. This effort aims to empower women farmers to ensure food security and sustainability while also promoting alternative income alternatives, allowing them to make decisions that will substantially influence poverty reduction. Finally, to eradicate hunger and poverty, women should be trained in agricultural best practices, operation, and water irrigation, among other things.

if The study also discovered that most women continue to in face difficulties, such as a lack of infrastructure, a poor healthcare system, lack of technology and a low standard of living, indicating that poverty has not decreased. In order 
programs

and

determine the extent of poverty among women in Anambra state.

(Asayehegn The determine how et al., 2012) effective development agents are at disseminating agricultural technology through the agricultural extension service.

(Kabir et It's essential to al., 2013) consider the possible factors that influence households' decisions to use biogas plants technology

(Nyamba \& The three goals were Mlozi, to look at the 2012) elements that influence how mobile phones are used to communicate agricultural information in rural Tanzania. They were to examine the type of agricultural information that farmers send and/or receive using mobile phones and the amount of ownership by farmers in the research area.

(Asfaw et This article assesses al., 2012) the potential benefit to eradicate poverty, the study proposed that the government focus its poverty reduction strategies on multidimensional indices (excellent infrastructure, sound health care system, etc.). As a result, this research shows that technology adoption and other infrastructure facilities are vital for empowering the community.

The development agents' regular engagements included transferring technology to target farmers, motivating the local community for collective action to solve communitywide challenges, distributing inputs, and providing training to farmers. A large number requires agricultural extension services of farmers. It is also critical to have this training for things that have not been done before.

Socio-economic characteristics heavily influence the respondents' attitudes about biogas adoption. The research findings revealed that the year of schooling, income level, number of cattle, and whether or not a woman heads a household had substantial influences on the decision to establish a biogas plant. As a result, efforts such as improving education, empowering women, boosting annual income, and raising the number of cattle are expected to increase the adoption rate of biogas plants.

The acceptance of mobile phone technology in rural Tanzania was high enough to be accompanied by a predictable beneficial economic impact. Regarding mobile phone access to agricultural information, it was clear that people in the research area use the expanding number of mobile phones to their benefit, to get information about their farming business. Mobile phones were rated by the majority of respondents as a simple, quick, and handy way to communicate agricultural information. Mole phone ownership, the type of agricultural information to be sent, the farming system used, network coverage, and respondents' socio-economic characteristics were all factors that influenced mobile phone use in sharing agricultural information.

Endogenous switching regression is used to quantify the causal influence of technology adoption by adjusting for the 
of improved legume technology on household welfare as assessed consumption expenditure in rural Ethiopia and Tanzania

(Dagunga This study analyzes et al., 2020) whether village saving organizations improve the welfare impact of agricultural

technology adoption using farm-level data collected from the Garu and Tempane districts in Ghana's Upper East Region.

(Friis- $\quad$ Farmer Field Schools Hansen \& (FFS), an extension Duveskog, technique favoring 2012) agriculture

development

programs in several African nations, are investigated for their empowerment and well-being effects. effects of the selection problem on production and adoption decisions. In rural Ethiopia and Tanzania, adopting new agricultural technologies has a large beneficial influence on consumption expenditure (per adult equivalent terms). This shows the potential importance of technology adoption in enhancing rural household wellbeing since increased consumption expenditure from improved technologies translates to lower poverty, more food security, and increased risk tolerance. Inadequate local seed supply, availability to knowledge, and perceptions of novel cultivars were identified as significant barriers to technology adoption in a study on the determinants of adoption.

Farmers' involvement in village saving clubs boosts the welfare impact of agricultural technology adoption. Farmers' decisions are influenced by other factors such as age, household size, and years of schooling. The study proposes that village saving organizations be promoted since they increase rural farmers' capacity to save for farm investment, allowing them to adopt more agricultural technology in their desire to improve farmer welfare. In addition, policy instruments such as extension service revitalization, the development of FBOs, and access to farm credit should be improved in this effort.

The most significant impact of FFS might be seen as increasing local people's power to make choices and decisions that lead to higher adoption of "agricultural innovations, access to services, and market access, as well as collective action". In order to generate an adequate combination of technological and social advances for a development process that is sustainable in nature, agricultural development programs should focus more on processes of empowering farmers rather than technical solutions, which characterize most programs.

The findings indicate that strategies that encourage empowerment and technology adoption simultaneously, rather than separately, could improve individual and household well-being to a higher degree. Understanding how, by whom, and for what purpose these technologies are used can support development partners in improving long-term sustainability. This evidence would contribute to the conservation of food and nutrition and the sustainability and empowerment of the community, especially in developing countries. These tools can help farmers receive vast information regarding agricultural technologies (most up-to-date information on agricultural produce practices). Technology adoption has been used to create a new direction of agriculture in many countries, and they are now the backbone of the poverty alleviation process among the agricultural communities. 
Farmers in the agriculture sector use multiple technologies to improve livelihood skills to accomplish empowerment

Technology adoption is generally grouped into three categories such as; soft technology, hard technology, and organizational technologies. Understanding the differentiation between technology types and their competitive advantages and similarities is critical to understanding how technology is practiced in agriculture. Soft technology refers to disseminating knowledge, skills, process, and practice and the conduct of multiple types of research to improve agricultural productivity and efficiency. Meanwhile, hard technology refers to materials, machinery, and other related equipment like cultivating new varieties, using recommended fertilizer, water, chemicals, and various types of machinery (tractors, seeders, combine harvesters, etc.). Technology ownership and administrative structures are referred to as organizational technologies (i.e., farmer field school). This mechanism controls all technological packages (Adnan et al., 2017; United Nations, 2014). The aforementioned technology adoption types can summarize in Table 3 based on the current SLR study as below;

Table 3: Summarize technology adoption categories into main three category

\begin{tabular}{l}
\hline \multicolumn{1}{c}{ Source } \\
\hline (Kabir et al., 2013) \\
(Asayehegn et al., 2012) \\
(Lwoga et al., 2011) \\
(Asfaw et al., 2012) \\
(Dagunga et al., 2020) \\
(Mango et al., 2018) \\
(Nyamba \& Mlozi, 2012) \\
(Odini, 2014) \\
(Ozoh et al., 2020)
\end{tabular}

$\begin{gathered}\text { Technology } \\ \begin{array}{c}\text { Adoption } \\ \text { Category }\end{array} \\ \text { practices }\end{gathered}$
pechnology Adoption in the grass-root level
prechnos

Soft Technology - The adoption of biogas technology. The household's adoption behavior toward biogas technology. Local awareness of the benefits of biogas contributing to successful large-scale uptake of the technology.

- The development agents" regular engagements works given by their hosting organization included transferring technology to target farmers, mobilizing the local community for group action to solve community-wide problems and giving training to farmers.

- The primary sources of information of farmers were mostly local neighbors, friends, family, and public extension agencies. Aside from radio and cell phones, sophisticated technology (such as the internet and e-mail) and printed materials were used frequently due to their widespread availability.

- Adoption of improved chickpea and pigeon pea technologies on household welfare measured.

- Adoption of agriculture technology in the quest to improve farmers' welfare. The membership of VSLA and the adoption of Zai technology independently improve farmers' welfare.

- The adoption of small-scale irrigation farming knowledge and skills as a climate-smart agriculture practice can influence the income of smallholder farmers. 
(Kabir et al., 2013) Hard

(Asayehegn et al., 2012) Technology

(Dagunga et al., 2020)

(Mango et al., 2018)

(Ozoh et al., 2020)

(Hailu et al., 2014)

(Friis-Hansen

\& Duveskog, 2012)
Organizational

Technologies
- Access to agricultural information through mobile phones and mobile phones to access information related to their farming business is a convenient way of communicating agricultural information.

- The improvement of the existing information services, systems, and channels of communication; information on farming practices with including pre harvesting and post harvesting practices.

- Women in micro-business have no access to programs and are multi-dimensionally poor; according to this study, therefore technology adoption is vital to community empowerment.

- Diversified farms activities: its range of agricultural products is one type of land-use change or adaptation in agriculture.

- The adoption of biogas technology. Adopt biogas plant and enable the installation of the biogas plant. The desire to adapt was combined with the availability of subsidies and a soft credit. Contributing to successful large-scale uptake of the technology.

- The development agents" regular engagements works given by their hosting organization included supplying inputs to farmers.

- The membership of VSLA and the adoption of Zai technology, access to farm credits (kind or cash).

- Small-scale irrigated farming is becoming more popular as a climate-smart agriculture practice can influence the income of smallholder farmers.

- According to this study, women in micro-business have no access to programs and are multidimensionally poor; therefore, physical facilities are vital to community empowerment.

- Adoption of agricultural technology by rural families, including drivers of chemical fertilizer and HYV adoption.

- FFS can be considered as a means of enhancing local people's ability to make choices and decisions that lead to higher adoption of agricultural technologies, access to services, and market access, as well as collective action.

It is critical to apply all three types of technologies in terms of their contribution to the agricultural sector's survival and prosperity and their contribution to the empowerment of agricultural communities in developing countries, which is the critical point to poverty alleviation. Hard technologies or providing only subsidies without providing adequate soft 
technologies are often prioritized and used in isolation, which is a source of concern. That is not the proper way to achieve long-term development, which is the issue at hand and the subject of discussion. When actors in the agriculture sector use these all technologies, they must be adequately informed and use them appropriately (Figure 4).

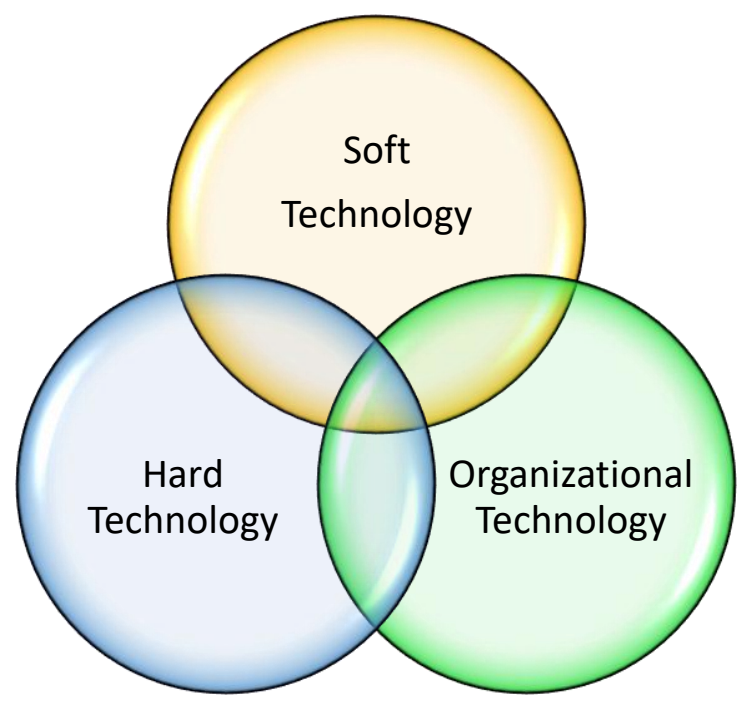

Figure 3: Mutual usage of technology adoption

Source: Author (2021) Based on the current literature review

The establishment of training centers, the scheduling of systematic knowledge sharing programs, and the provision of appropriate equipment/machinery and other necessary materials all contribute to the development of a robust mechanism for implementing technologies in the agriculture sector that provide farmers with expertise and knowledge on how to invest in technology to boost production and profits. Within nations in developing countries, there is a need for motivation and assistance in bringing all three types of technologies into operation in a mutually supportive manner (Figure 3 ). It must be ensured that innovations are used in a competitive and sustainable approach among the community in the agricultural sector.

\section{Norms and attitudes of communities are in obtain novel technology for empowerment in the agricultural sector}

Farmers' demands have resulted in a rise in technology adoption in developing countries in the past decade. Farmers always have looked to technology for cost-cutting and high-product opportunities in their livelihood activities. Furthermore, rising incomes, lower production costs, and more opportunities for value-added products are the driving forces of willingness to use technology in their livelihood activities. These factors stimulate the way of pursuing to move their thinking towards sustainable empowerment (Asfaw et al., 2012). Simultaneously, consumers are constantly demanding high quality and quantity products, which is a significant motivator for farmers to improve their products qualitatively and quantitatively. As a result, technology adoption is the most effective way to meet such objectives. According to the result, farmers in developing countries are always adaptable when incorporating technology into their livelihood activities. 
The adoption of technology is multifactorial, and it takes into account the goals of sustainable agriculture. When it comes to establishing new technology, there is a lot of risk and negotiation among the agricultural community. Innovations must lead to an economically thriving farm sector, financial sustainability for farmers, and improved environmental efficiency to generate sustainability. Technology evolves rapidly, and understanding the socio-economic consequences of implementing new technologies towards empowerment in agriculture (significant direct relationship) is often lacking. As a result, technology adoption decisions are made in an ambiguous setting, with a wide element of experimentation in its implementation, and the pace and extent of technology adoption and empowerment vary significantly among farmers. As a result, farmer norms and values may significantly impact farm structure and the number of farmers who can implement technology and protect their financial well-being by participating in agricultural development projects (Ozoh et al., 2020).

\section{Discussion and Recommendation}

The vast majority of people in developing countries live in rural areas, and agriculture is their primary source of income. According to recent scientific results, they make a significant contribution to global economic development; nonetheless, poverty is the main barrier to improving their living conditions and achieving sustainable development. As a result, the focus of this research is on the agricultural community in developing countries. The importance of technology adoption in the agricultural sector in developing countries has been recognized with the primary goal of meeting basic needs (food, income, shelter and so on) and enhances the living condition of them. Agriculture has progressed in developing countries in recent decades. The secret reason that the productivity of major agricultural and horticultural crops has increased is technology adoption; however, scientific research on the relationship between technology adoption and community empowerment still lacks in comparison to developed countries. Consequently, most technology adoption programs in developing countries lag behind the global average, directly impacting poverty alleviation through empowerment. Similarly, the efficiency of agricultural development programs in developing countries can be improved by fully understanding technological adoption and robust community development strategies such as empowerment.

In relation to the findings, it is critical for both the government and non-governmental organizations (NGOs) to provide job training for development agents in order to increase their capacity as extension experts in terms of knowledge, skill, and level of commitment, and thus be able to use and manage effectively cumulative extension methods and communication media. As a result, there is a need to improve working environment, including logistics, benefits, and advancement. As a result, the government, non-governmental organizations (NGOs), and community-based organizations (CBOs) must priorities the development of rural infrastructure facilities such as rural road construction, telecommunications (ICT), and transportation systems in order to make accessible to farmers and farmers to market services, allowing them to reduce input marketing costs, save labor and time, and improve their quality of life. According to the findings, delivering technology to target farmers, motivating the local community for collective action to address community-wide issues, sourcing inputs, and providing farmer training (Asayehegn et al., 2012).

Identifying individual farmer problems and referring them to subject matter experts, supporting credit and credit payback concerns, acting as a bridge between government, 
NGOs, research, and other private sectors to enhance livelihoods, and collecting government taxes (Asayehegn et al., 2012). In the early stages of technology adoption and dissemination, the government will need to take the lead in creating an enabling environment for effective private sector involvement. The most potential policy approach for accelerating and expanding adoption is better local availability of improved planting materials at reasonable rates, along with improved awareness campaigns for improved varieties. By enhancing access to agri-business development services and empowering cooperatives and village agrodealers, policymakers can encourage and aid private agro based enterprises and community based producer organizations (Asfaw et al., 2012).

Farm-level institutional and policy efforts to promote village saving groups should be strengthened. These savings groups can aid in the development of rural farm households' financial capacity, thereby promoting financial inclusion among rural farm dwellers. Farmers also have the freedom to plan for future agricultural investments because they can rely on stable savings and micro-credit. As a result, farmers can alleviate finance limitations, invest in agricultural operations through the use of farm technology, and increase production. Strengthening existing supply policy instruments like access to extension services and farmerbased organizations could help promote village savings groups and their consequent effects on agricultural technology adoption and wellbeing. Farmer-based organizations (FBOs) should make a concerted effort to encourage farmers to join village savings organizations by providing incentives to areas with well-functioning farmer groups and improving extension service delivery (Dagunga et al., 2020).

Policymakers should focus on overcoming credit market failures, irrigation problems by introducing drip and pipe irrigations, ensuring farm households' land ownership status, and empowering female-headed households to be participants and agents of change by considering a comprehensive approach (Hailu et al., 2014). By implementing new arrangements on subsidies, taxation, and other policies, the United Nations is dedicated to promoting sustainable renewable energy. The current subsidy and credit mechanisms can be maintained at a standard level, where men can see evident government incentives and public advertising of renewable energy and biogas technology can be disseminated to farming community. As a result, electronic and print media could support in the spread of technology across the community. The most essential aspects contributing to a successful large-scaleuptake of the technology are local awareness of the benefits of technology adoption and readiness to adapt, as well as the availability of subsidies and soft loans to enable the deployment of novel technologies (Kabir et al., 2013).

It is critical to have access to appropriate information and expertise in order to improve agricultural performance and lives in rural areas, particularly in African countries. To get agricultural information and knowledge, farmers have less trust on face-to-face contact, as well as radio and TV, rather than printed materials and modern ICTs such as the mobile phones, internet and e-mail (Lwoga et al., 2011). Furthermore, Lwoga et al. (2011) highlights the following suggestions are offered as a result of the findings:

- Studies on information and knowledge requirements are conducted on a regular basis. In order to address the varied demands of farmers, researchers, educators, extension 
agents, and agricultural support services should perform regular studies on information and knowledge needs.

- Information and knowledge sources mapping and awareness Researchers, educators, extension agents, agricultural support services, and village officials should collaborate to identify knowledge and information sources in the communities, as well as raise awareness of those resources. Farmers will be able to find what they need more easily and their confidence in obtaining and implementing new knowledge to improve their agricultural outputs will grow as an outcome.

- It is a culture of knowledge. Researchers, educators, extension agents, and agricultural support services should develop a culture of knowledge sharing in order to influence farmers' decisions to accept new knowledge, as well as to enable agricultural specialists to recognize and determine farmers' requirements and knowledge. Farmers are more inclined to adopt agricultural specialists' technology once they perceive that their own inputs are incorporated into the design and improvement of these technologies.

- Collaborative technology development and design. To improve the acceptance rate of agricultural knowledge and technology in local communities, researchers, educators, and extension agents should involve farmers in the design and development of agricultural technologies.

- There are numerous sources of information. To offer relevant information to farmers, researchers, educators, extension agents, and agricultural support services should employ different sources of information such as; community radio program, drama, and storytelling, as well as print media (such as brochures, newsletters, and books) and information and communication technologies (such as the internet, e-mail, and cell phones).

Develop strategies and polices for small-scale irrigated agriculture to ensure that farmers do not lose all of their agricultural produce as a result of climate change and unpredictability. Given that climatic unpredictability and change are becoming more prevalent in many developing countries, climate-smart agriculture practices including such small-scale irrigation agriculture must be prioritized (Mango et al., 2018). Rural community acceptance of mobile telecommunications is strong enough for a predictable positive financial development of their livelihood activities. As a result, their farmers markets, weather and other information projections that could be valuable for them were easy to follow and improved their standard of living. However, the characteristics of respondents, such as age, sex, daily income and education, have been found to have determined ownership and mobile telephone use in the area of research (Nyamba \& Mlozi, 2012). Additionally, Nyamba \& Mlozi (2012) recommended few policy to development of agriculture in rural area as;

- The government should lower mobile prices, particularly when mobile telephones in rural areas more price in terms of competition, so that many farmers can afford to buy and operate mobile telephones.

- Public ICT places should be introduced by the government, NGOs and other development agencies, particularly in rural areas where farmers are able to share agricultural information.

- It may be vital to provide rural people with education on the use, application modalities and benefits of mobile telephones.

It is important to deliver knowledge and skills, as well as relevant technology, to women farmers in order to inform them about innovative farming practices that would increase food 
production and security. Finally, as a means of eradicating hunger and poverty, women should be trained in agricultural best practices, operation, and irrigation, among other things. It is also suggested that information centers, such as libraries compile, maintain, and disseminate information on proper agricultural techniques from relevant organizations, as well as participate in the distribution process (Odini, 2014).

This review focused on critically analyzing previous research on the matter and coming up with new ideas. In developing countries, there are a significant number of people live in poverty and backwardness in rural areas. Since agriculture and agro-based industries are the sole sources of income in rural areas in developing countries, adopting technology and implementing community development strategies will help to improve people's living conditions and alleviate poverty. There are several innovations and individuals engaged in agriculture and further research needs to be focused on farming practices that need resources and knowledge about how to use them best to empower agricultural communities and alleviate poverty.

\section{Conclusion}

In conclusion, the empowerment among the farming community in developing countries positively affects poverty alleviation through the adoption of technology in their development activities. Poverty alleviation often requires income-generating activities among the poor rural farmers; these income streams significantly impact both people's empowerment and poverty alleviation efforts. According to the findings of numerous research papers, technology adoption is a significant turning point in agricultural production, resource utilization (land, seeds, planting materials, fertilizer application, pest and disease control, and other agricultural practices), and earnings, which affect improving living status and empowerment, either directly or indirectly. Governments and non-profit organizations provide income-generating programs to the agricultural community that includes a variety of technology packages. The most critical aspect of empowerment is education and technology adoption. This study aims to determine the level of technology adoption among respondents and its effect on empowerment. According to the findings, the majority of participants have a high level of technological adoption. Poverty alleviation and long-term development are major concerns in developing countries. The most significant development challenges are a lack of technological adoption and other infrastructure facilities for their livelihood operations. However, based on SLR analysis of 11 research papers, it seems that it has contributed in a variety of ways to local community development in the area, including the use of appropriate technologies, provision of adequate infrastructure and other physical materials, and institutional support to help the community to build their capacity. Based on a critical examination of previous research articles' strategies, approaches, and policies, the current article (SLR study) suggests that adequate technology adoption and other supportive facilities should be encouraged to minimize unsustainable development and motivate the farming community to achieve its development goals. It is concluded that other researchers will use the current SLR findings to improve their understanding and conduct a study. Policymakers can utilize these findings to build new policies in developing countries to establish new agricultural policies that will empower their farming communities. Finally, these assist the various government and non-governmental organizations in developing countries in planning new agricultural development programs. 


\section{Reference}

Adnan, N., Nordin, S. M., \& bin Abu Bakar, Z. (2017). Understanding and facilitating sustainable agricultural practice: A comprehensive analysis of adoption behaviour among Malaysian paddy farmers. Land Use Policy, 68(August), 372-382. https://doi.org/10.1016/j.landusepol.2017.07.046

Ahmad, P., Yusof, F., \& Abdullah, F. (2013). Local Economic Growth and Community Sustainability. Procedia - Social and Behavioral Sciences, 101, 437-444. https://doi.org/10.1016/j.sbspro.2013.07.217

Ajani, E., Mgbenka, R., \& Onah, O. (2015). Empowerment of Youths in Rural Areas through Agricultural Development Programmes : Implications for Poverty Reduction in Nigeria. International Journal of Research in Agriculture and Forestry Volume, 2(2), 34-41.

Asayehegn, K., Weldegebrial, G., \& Kaske, D. (2012). Effectiveness of development agents' performances in agricultural technology dissemination: The case of Southern Nations Nationalities and Peoples Regional State (SNNPRS), Ethiopia. Journal of Agricultural Extension and Rural Development, 4(17), 446-455.

https://doi.org/10.5897/JAERD11.150

Asfaw, S., Shiferaw, B., Simtowe, F., \& Lipper, L. (2012). Impact of modern agricultural technologies on smallholder welfare: Evidence from Tanzania and Ethiopia. Food Policy, 37(3), 283-295. https://doi.org/10.1016/j.foodpol.2012.02.013

Bishop, K., \& Phillips, A. (2012). Countryside Planning: New Approaches to Management and Conservation. Earthscan. https://books.google.com.my/books?id=IGq-KLtpkZYC

Brennan, M. A. (2007). Revised and Resubmitted to the International Journal of Volunteer Administration February 2007. The International Journal of Volunteer Administration, 24(4), 5-13.

Cremin, P., \& Nakabugo, M. G. (2012). Education, development and poverty reduction: A literature critique. International Journal of Educational Development, 32(4), 499-506. https://doi.org/10.1016/j.ijedudev.2012.02.015

Dagunga, G., Amoakowaa, A., \& Ehiakpor, D. S. (2020). Interceding role of village saving groups on the welfare impact of agricultural technology adoption in the Upper East Region, Ghana. Scientific African, 8(00433), 1-10.

FAO. (2020). The state of Food Securiety and Nutrition in the World. Www.Fao.Org.

Friis-Hansen, E., \& Duveskog, D. (2012). The Empowerment Route to Well-being: An Analysis of Farmer Field Schools in East Africa. World Development, 40(2), 414-427. https://doi.org/10.1016/j.worlddev.2011.05.005

Gergis, A. (1999). Citizen Econmic Empowerment in Botswana: Concepts and principles (Issue 22).

Hailu, B. K., Abrha, B. K., \& Weldegiorgis, K. A. (2014). Adoption and Impact of Agricultural Technologies on Farm Income: Evidence From Southern Tigray, Northern Ethiopia. International Journal of Food and Agricultural Economics, 2(4), 91-106. https://doi.org/10.22004/ag.econ.190816

Halkos, G., \& Gkampoura, E. C. (2021). Where do we stand on the 17 Sustainable Development Goals? An overview on progress. Economic Analysis and Policy, 70, 94122. https://doi.org/10.1016/j.eap.2021.02.001

Hussain, M. D., Bhuiyan, A. B., \& Bakar, R. (2014). Entrepreneurship Development and Poverty Alleviation: an Empirical Review. Journal of Asian Scientific Research, 4(10), 558-573. http://www.aessweb.com/journals/5003

Jeníček, V. (2011). Developing countries: trends, differentiation. Agriculture Economics- 
CZECH, 57(4), 175-187.

Kabir, H., Yegbemey, R. N., \& Bauer, S. (2013). Factors determinant of biogas adoption in Bangladesh. Renewable and Sustainable Energy Reviews, 28, 881-889. https://doi.org/10.1016/j.rser.2013.08.046

Kassie, M., Fisher, M., Muricho, G., \& Diiro, G. (2020). Women's empowerment boosts the gains in dietary diversity from agricultural technology adoption in rural Kenya. In Food Policy (Vol. 95). https://doi.org/10.1016/j.foodpol.2020.101957

Latopa, A. A. (2015). Analysis of Values and Principles of Community Development: A Response to the Challenges of Building a New Nigeria. At the 7th Annual National Conference of the College of Administrative Studies and Social Sciences (C.A.S.S.S.), Kaduna Polytechnic Held between 2nd - 6th November 2015 at the Department of Public Administration Lecture Hall, C.A.S.S.S. Bye- Pass Campus, November, 1-22.

Lwoga, E. T., Stilwell, C., \& Ngulube, P. (2011). Access and use of agricultural information and knowledge in Tanzania. Agricultural Information and Knowledge, 60(5), 383-395. https://doi.org/10.1108/00242531111135263

Mango, N., Makate, C., Tamene, L., Mponela, P., \& Ndengu, G. (2018). Adoption of small-scale irrigation farming as a climate-smart agriculture practice and its influence on household income in the Chinyanja Triangle, Southern Africa. Land, 7(2), 1-19. https://doi.org/10.3390/land7020049

Mujtaba, K. G., Abu, S. A., Hanina, H., \& Nobaya, A. (2016). Empowerment among small farmers of Sindh Province, Pakistan. Asian Journal of Agriculture and Rural Development, 6(3), 41-49. https://doi.org/10.18488/journal.1005/2016.6.3/1005.3.41.49

Muzari, W., Gatsi, W., \& Muvhunzi, S. (2012). The Impacts of Technology Adoption on Smallholder Agricultural Productivity in Sub-Saharan Africa: A Review. Journal of Sustainable Development, 5(8), 69-77. https://doi.org/10.5539/jsd.v5n8p69

Nyamba, S. Y., \& Mlozi, M. R. S. (2012). Factors Influencing the Use of Mobile Phones in Communicating Agricultural Information: A Case of Kilolo District, Iringa, Tanzania. International Journal of Information and Communication Technology Research, 2(7), 558-563.

Odini, S. (2014). Access to and Use of Agricultural Information by Small Scale Women Farmers In Support of Efforts to Attain Food Security in Vihiga County, Kenya. Journal of Emerging Trends in Economics and Management Sciences (JETEMS), 5(2), 100-107.

Ozoh, J. N., Metu, A. G., Stephen M., C., \& Madueke, C. (2020). Poverty Alleviation Programme and Poverty Reduction in Anambra State. Evidence from Women Business Ownership. Advances in Social Sciences Research Journal, 7(1), 217-229. https://doi.org/10.14738/assrj.71.7546

Peters, M. D. J., Godfrey, C. M., Khalil, H., Mclnerney, P., Parker, D., \& Soares, C. B. (2015). Guidance for conducting systematic scoping reviews. International Journal of EvidenceBased Healthcare, 13(3), 141-146. https://doi.org/10.1097/XEB.0000000000000050

Purcell, R. (2012). Community development and everyday life. Community Development Journal, 47(2), 266-281. https://doi.org/10.1093/cdj/bsq058

Ramdhani, A., Ramdhani, M. A., \& Amin, A. S. (2014). Writing a Literature Review Research Paper : A step-by-step approach. International Journal of Basic and Applied Science, 3(1), 47-56.

Rita, F. Y., \& Laosebikan, J. (2021). Poverty and unemployment: entrepreneurship the Panacea? Hallmark University Journal of Management and Social Sciences (HUJMS, 3(1), 57-65. 
Ifeoma, R. A., Purity, N.-O., \& Yusuf, A. (2018). Effect of Entrepreneurship Development on Poverty Alleviation in Nigeria. IOSR Journal of Business and Management (IOSR-JBM), 20(2), 80-87. https://doi.org/10.9790/487X-2002108087

Rodriguez-Pose, A., \& Hardy, D. (2015). Addressing poverty and inequality in the rural economy from a global perspective. Applied Geography, 61, 11-23. https://doi.org/10.1016/j.apgeog.2015.02.005

Sarania, R. (2015). Impact of Self-Help Groups on Economic Empowerment of Women in Assam. International Research Journal of Interdisciplinary \& Multidisciplinary Studies (IRJIMS), 1(1), 148-159.

Sutter, C., Bruton, G. D., \& Chen, J. (2019). Entrepreneurship as a solution to extreme poverty: A review and future research directions. Journal of Business Venturing, 34(1), 197-214. https://doi.org/10.1016/j.jbusvent.2018.06.003

Talero, E., \& Gaudette, P. (1996). Harnessing Information for Development A Proposal for a World Bank Group Strategy. The World Bank Washington, D.C.

Tanga, P. T., \& Mundau, M. (2014). The impact of donor-funded community empowerment projects on poverty alleviation in Zimbabwe. Perspectives on Global Development and Technology, 13(4), 465-480. https://doi.org/10.1163/15691497-12341312

Theis, S., Lefore, N., Meinzen-Dick, R., \& Bryan, E. (2018). What happens after technology adoption? Gendered aspects of small-scale irrigation technologies in Ethiopia, Ghana, and Tanzania. Agriculture and Human Values, 35(3), 671-684.

https://doi.org/10.1007/s10460-018-9862-8

Ugochukwu, A., \& Phillips, P. (2018). Technology Adoption by Agricultural Producers: A Review of the Literature. In Innovation, Technology, and Knowledge Management, Springer. Springer International Publishing AG, Gewerbestrasse 11, 6330 Cham, Switzerland.

https://doi.org/10.1007/978-3-319-67958-7

United Nations. (2014). Technologies for Adaptation in the Agriculture Sector. In United Nations Framework Convention on Climate Change. Technology Excecutive Committee.

Uziak, J., \& Lorencowicz, E. (2017). Sustainable Agriculture - Developing Countries Perspective. IX International Scientific Symposium "Farm Machinery and Processes Management in Sustainable Agriculture", Lublin, Poland, November, 389-394. https://doi.org/10.24326/fmpmsa.2017.70 